\title{
Modeling of PEM Fuel Cell Based Power
}

\section{Generation System}

\author{
Pooja Chavadi ${ }^{1}$, Sonali Pandit ${ }^{2}$ \\ PG student, Electrical and Electronics, Goa College of Engineering, Ponda Goa, India ${ }^{1}$ \\ Assistant Professor, Electrical and Electronics, Goa College of Engineering, Ponda Goa, India ${ }^{2}$
}

\begin{abstract}
The rising cost of electricity and environmental concerns have driven research in the renewable energy resources such as wind energy, PV modules and fuel cells etc. Power generation using fuel cell (FC) is getting attention day by day. In fuel cell electrochemical reaction takes place to generate electricity in which water is formed due to oxygen and hydrogen reaction. Advantage of fuel cell is that it emits less $\mathrm{CO}_{2}$. Fuel cell types are generally classified according to the electrolyte nature they use. In this paper, modeling and Simulation of PEM (proton exchange membrane) FC stack is carried out in Matlab/Simulink environment. The output of FC stack model is connected to step-up boost converter, single phase H bridge inverter using the Sim Power Systems of Matlab to get an AC output.
\end{abstract}

Keywords: Renewable Energy, Fuel Cell, Boost Converter, single phase H Bridge Inverter.

\section{INTRODUCTION}

Generation of renewable electricity helps in reducing carbon dioxide (CO2) emission in the environment and hence many countries have switched to generate electricity through renewable resources such as solar and wind plants to reduce the content of $\mathrm{CO} 2$. But generation of electricity using these resources have certain drawbacks such as wind tends to blow intermittently and solar energy is available only during day time. The prime advantage of FC is they are used for transportation applications such as electric vehicle or mobile systems (portable power supplies).Looking into all these aspects fuel cell technology is been used to generate electricity and these plants are being installed in many countries.

This paper discussed about the fuel cell mainly the PEM fuel cell which refers as proton exchange membrane in which a proton conductive membrane is used as the electrolyte and at the same time as the separator in the electrochemical cell to separate the anode from the cathode. Because this type of fuel cell membrane electrolyte operates on protons, any oxidisable hydrogen rich fuel such as hydrogen gas, lower alcohols and acids can be used. Therefore this are also referred to as distributed generation (DG). Fuel cells can provide both heat and electricity hence it has drawn more attention towards DG. Additional cooling channels can be added to fuel cell. A fuel cell is an electrochemical device which converts chemical energy of fuel directly into electrical energy. Impact of environment is low on fuel cell and is highly efficient and long life time. Hence they are a very good option as a DG. [1]. To produce commercial AC power a power conditioning stage is essential since the output of a fuel cell is dc electricity. However, when fuel cell stack is connected to distribution network, problems in power quality and power flow control need to be resolved. To solve these problems and to regulate current, voltage and power transmitted into the load an power conditioning system (PCS) is developed. The majority of commonly used renewable energy sources deliver electric power at the output voltage range of $12 \mathrm{VDC}$ to $38 \mathrm{VDC}$ which is quite low. To adjust it to the electric load standards that voltage should be boosted to the system DC Bus voltage of around $50 \mathrm{~V}$ or $100 \mathrm{~V}$ DC depending on the load requirements. Power conditioning can be accomplished by high efficiency step-up DC/DC (boost) converters. The output voltage of dc to dc converter is fed to a DC/AC inverter to the load. The Complete block diagram of proposed system is shown in fig (1).

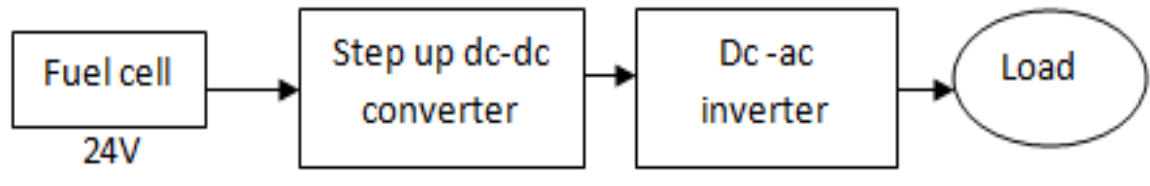

$50 \mathrm{~V}, 1 \mathrm{~A} \quad 50 \mathrm{~V}$

Fig.1: System block diagram 
1 .Principle of operation

\section{PROTON EXCHANGE MEMBRANE FUEL CELL}

PEM fuel cell transforms the chemical energy liberated during the chemical reaction of oxygen and hydrogen to electrical energy. A stream of hydrogen is delivered to the anode side of the membrane. These further will get split to protons and electrons. This hydrogen oxidation reaction (HOR) is given in the following equation [2]

\section{Anode side:}

\section{$\mathrm{H}_{2}-\mathbf{2} \mathrm{H}^{-}+2 \mathrm{e}^{-}$}

These protons formed travel through the polymer membrane to reach the cathode side. And the electrons which are formed travel through the load circuit to reach cathode of the membrane to create the current output .At the same time the group of oxygen molecules delivered to the cathode side. At the cathode side oxygen molecules react with the protons and electrons to form an water molecule. This type of reaction oxygen reduction reaction (ORR) is given in the following equation

\section{Cathode side:}

$\mathrm{O}_{2}+4 \mathrm{H}^{+}+4 \mathrm{e}^{-}-2 \mathrm{H}_{2} \mathrm{O}$

Over all reaction:

\section{$\mathrm{O}_{2}+2 \mathrm{H}_{2} 2 \mathrm{H}_{2} \mathrm{O}+\mathrm{HEAT}+\mathrm{ELECTRICITY}$}

The reversible reaction is expressed in the equation and shows the reincorporation of the hydrogen protons and electrons together with the oxygen molecule and the formation of one water molecule. Basic operation of PEMFC is shown in fig (2). The V-I characterises of basic Full cell is shown in Fig.3

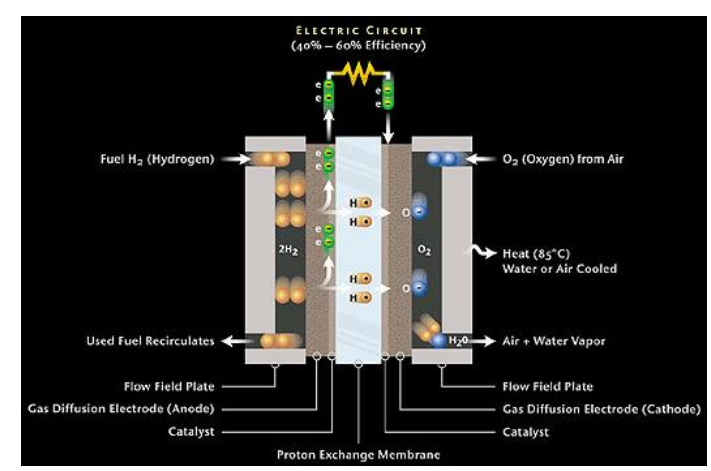

Fig 2. Basic operation of PEMFC [2]

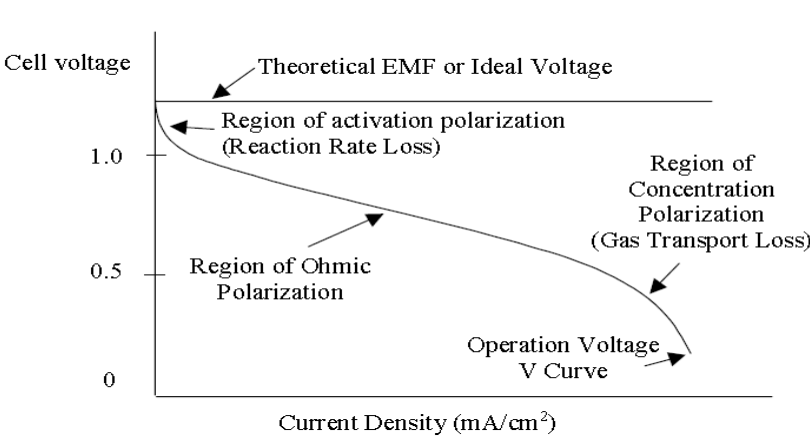

Fig.3 V-I characteristics of fuel cell [1]

\section{Electrochemical Modeling of PEM Fuel Cell}

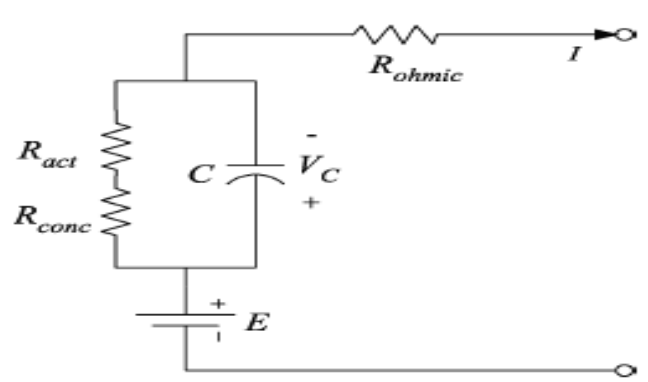

Fig 4. Equivalent electrical circuit of the double layer charging effect inside the PEM fuel cell [1]

Equivalent electrical circuit of the double layer charging effect inside the PEM fuel cell is shown in fig 4.

A. Fuel-Cell Output Voltage [3].

The modeling of the PEM fuel cell is based on following design equations :

$\mathbf{V}_{\text {cell= }}$ Ecell-Vact,cell- $\mathbf{V}_{\text {ohm,cell }}-\mathbf{V}_{\text {conc,cell. }}$

The output voltage of the fuel-cell stack can be obtai ned as

$\mathbf{V}_{\text {out }}=\mathbf{N}_{\text {cell }} \mathbf{V}_{\text {cell }}=\mathbf{E}-\mathbf{V}_{\text {act }}-\mathbf{V}_{\text {ohm }}-\mathbf{V}_{\text {conc. }}$

Where $\mathrm{V}_{\text {cell }}=$ output voltage of fuel cell

$\mathrm{E}_{\text {cell }}=$ reversible potential

$\mathrm{V}_{\text {act }}=$ Activation voltage loss 
$\mathrm{V}_{\mathrm{ohm}}=$ Ohmic voltage loss

$\mathrm{V}_{\text {conc }}=$ Concentration voltage loss

$\mathrm{N}_{\text {cel }}=$ Number of cells in the stack.

To calculate fuel cell voltage output following estimations are used:

1) Activation voltage loss:It is due to electrode kinetics. During electrochemical reactions, there is a voltage drop in order to provide continuous current by giving necessary activation energy. Tafel equation, given below is used to calculate the activation voltage loss in fuel cell

An empirical equation for $\mathrm{V}_{\text {act }}$ is given in [1], where a constant $\eta \mathrm{o}$ is constant:

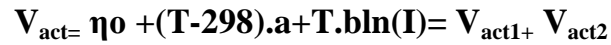

Where $\mathrm{V}_{\text {act1 }}=(\eta \mathrm{O}+(\mathrm{T}-298) \cdot \mathrm{a})$ is the voltage loss affected only by the fuel cell internal temperature, while $\mathrm{V}_{\text {act2 }}=($ $\mathrm{T} . \mathrm{bln}(\mathrm{I}))$ is both current and temperature dependent.

2) Ohmic voltage loss: At medium current ,ohmic loss causes voltage losses caused by ionic resistance in the electrolyte and electronic resistance in electrodes. The overall ohmic voltage loss can be expressed as:

$\mathbf{V}_{\text {ohm }}=\mathbf{I R}_{\text {ohm }}$

Where $\mathrm{R}_{\mathrm{ohm}}$ is the ionic resistance in the electrolyte and electronic resistance in electrodes.

3) Concentration voltage loss: At high currents voltage concentration becomes more important . During the reaction process, concentration gradients can be formed due to mass diffusions from the flow channels to the reaction sites (catalyst surfaces). The concentration over potential in the fuel cell is defined as

$\mathbf{V}_{\text {conc }}=-\frac{\mathrm{RT}}{\mathrm{zF}} \ln \frac{\mathrm{Cs}}{\mathrm{CB}}$

Where $C$ s is the surface concentration and is the bulk concentration $C_{B}$ is the bulk concentration.

B. Energy balance of the thermodynamics:

The net heat generated by the chemical reaction inside the fuel cell, which causes its temperature to rise or fall ,can be written as

$\mathbf{q}_{\text {net }}=\mathbf{q}_{\text {chem }}-\mathbf{q}_{\text {elec }}-\mathbf{q}_{\text {sens+latent-qloss }}$

The temperature of the fuel cell will rise or drop according to the following equation

$\mathbf{M}_{\mathrm{fc}} \mathbf{C}_{\mathrm{fc}} \mathrm{dT} / \mathrm{dt}=\mathrm{qnet}$

Where $\mathrm{M}_{\mathrm{fc}}$ is the total mass of the fuel-cell stack and $\mathrm{C}_{\mathrm{fc}}$ is the overall specific heat capacity of the stack.

The specifications of fuel-cell stack are given in Table I. [3] The electrical model parameter values used in the simulation studies are listed in Table II.

Specifications of fuel-cell stack Table I

\begin{tabular}{|l|l|}
\hline Parameters & Values \\
\hline Temperatures( T[K]) & $5^{0} \mathrm{C}$ to $35^{\circ} \mathrm{C}$ \\
\hline No. of cells & 48 \\
\hline Operating Pressures & $\begin{array}{l}\mathrm{P}_{\mathrm{H} 2}=1.5 \mathrm{~atm} \text { and } \\
\mathrm{P}_{\text {cathode }}=1.0 \mathrm{~atm}\end{array}$ \\
\hline System Efficiency & $>50 \%$ \\
\hline Relative Humidity & $5-95 \%$ \\
\hline
\end{tabular}

Electrical model parameter Table II

\begin{tabular}{|c|c|c|c|}
\hline $\mathrm{E}_{0}{ }^{0}(\mathrm{~V})$ & 58.9 & $\mathrm{C}_{\mathrm{h}}(\mathrm{f})$ & 22000 \\
\hline $\mathrm{K}_{\mathrm{E}}(\mathrm{V} / \mathrm{K})$ & 0.00085 & $\mathrm{R}_{\mathrm{t}}(\Omega)$ & 0.0347 \\
\hline$\eta_{0}$ & 20.145 & $\mathrm{C}(\mathrm{f})$ & $\begin{array}{c}0.1 \mathrm{~F}(4.8 \mathrm{~F} \text { for each } \\
\text { cell })\end{array}$ \\
\hline$\lambda_{\mathrm{e}}$ & 0.00333 & $\mathrm{R}_{\mathrm{ohm} 0}(\Omega)$ & 0.2793 \\
\hline $\mathrm{a}(\mathrm{V} / \mathrm{K})$ & -0.1373 & $\mathrm{R}_{\mathrm{ohm} 1}(\Omega)$ & $0.001872^{*} \mathrm{I}$ \\
\hline $\mathrm{e}(\mathrm{s})$ & 80 & $\mathrm{R}_{\mathrm{ohm} 2}(\Omega)$ & $-0.0023712^{*} \mathrm{~T}-298$ \\
\hline $\mathrm{R}_{\mathrm{act} 0}(\Omega)$ & 1.2581 & $\mathrm{R}_{\text {conc } 0}(\Omega)$ & 0.080312 \\
\hline $\mathrm{R}_{\mathrm{act} 2}(\mathrm{C})$ & $\begin{array}{c}0.00112 *( \\
\mathrm{T}-298)\end{array}$ & $\left.\mathrm{R}_{\text {conc } 2} \Omega\right)$ & $\begin{array}{c}0.00002747^{*}(\mathrm{~T}- \\
298)\end{array}$ \\
\hline
\end{tabular}


The electrochemical model of fuel cell simulated using MATLAB is given below in Fig.5. The simulated results are shown in Fig 5.1 shows V-I Characteristics of Fuel Cell and Fig 5.2 shows P-I Characteristics of Fuel Cell

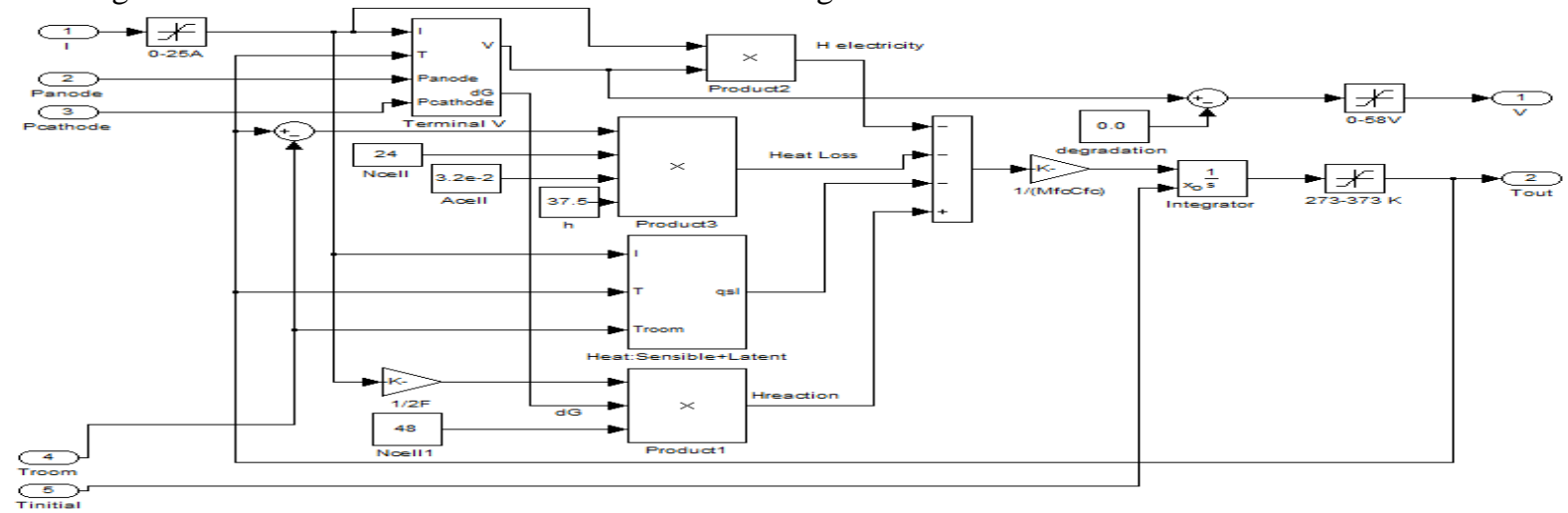

Fig 5 Mathematical model of PEM fuel cell

\section{BOOST CONVERTER}

The step up boost converter is used to convert the dc input of an PEMFC to a dc output at a desired voltage level by adjusting duty cycle. The boost converter connected to a FC module with a resistive load is illustrated in Fig.6. The duty cycle of the converter is given by[4]

Duty cycle $\mathrm{D}=1-\frac{\mathrm{Vin}}{\text { Vout }}$

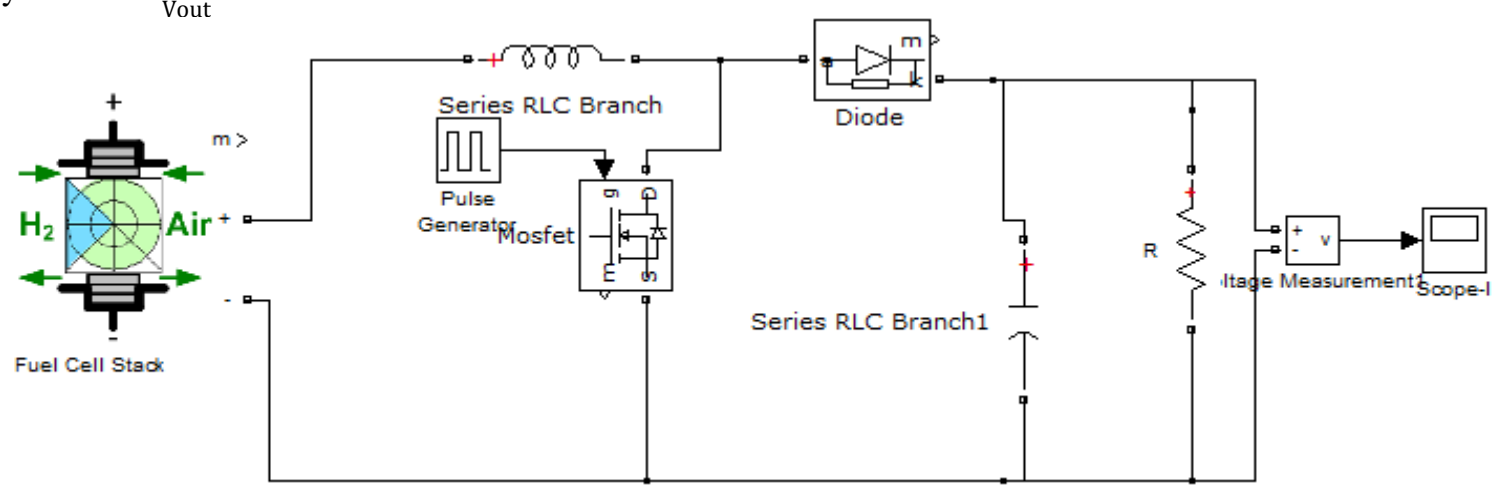

Fig 6. Boost converter

Capacitance and Inductance can be selected on bases of following design formulae:

$\mathbf{C}=\mathbf{I}_{0} \mathbf{D} / \mathbf{F s} \Delta \mathbf{V}_{0}$

Where $\mathrm{V}_{0}$ represents the output voltage $(\mathrm{V})$, D represents the duty cycle, Fs represents frequency $(\mathrm{Hz}), \mathrm{I}_{0}$ is the output current.

\section{$\mathbf{L}=\mathbf{V}_{\mathbf{S}} \mathbf{D} / \mathbf{F s} \Delta \mathbf{I}$}

Where $\mathrm{v}_{\mathrm{s}}$ represents the source voltage $(\mathrm{V})$ and $\Delta \mathbf{I}$ represents inductor ripple current.

an boost converter with fuel cell as power source is simulated in matlab with the parameters as shown in table-III and the simulated results are shown in fig 6.1 for voltage boosted to $50 \mathrm{~V}$ and fig 6.2 for current of $1 \mathrm{~A}$.

TABLE -III Boost converter design parameters

\begin{tabular}{|l|l|}
\hline Parameters & Value \\
\hline Fuel cell source- $\mathrm{V}_{\text {in }}[\mathrm{V}]$ & $24-38$ \\
\hline Load resistance, $\mathrm{R}$ & $50 \mathrm{ohm}$ \\
\hline Inductance, $\mathrm{L}[\mathrm{mH}]$ & $0.24 \mathrm{mH}$ \\
\hline Capacitance, $\mathrm{C}[\mu \mathrm{F}]$ & $200 \mu \mathrm{F}$ \\
\hline Frequency, $\mathrm{F}$ & $10 \mathrm{KHz}$ \\
\hline Duty ratio & 0.52 \\
\hline Output voltage & 50 \\
\hline
\end{tabular}




\section{DC/AC INVERTER}

In this paper single phase $\mathrm{H}$ bridge inverter is used. Dc voltage from the boost converter is inverted to ac voltage. Switches are triggered using PWM technique [5].Fig 7 shows the MATLAB model of single phase $\mathrm{H}$ bridge inverter circuit and simulated inverter results are shown in fig 7.1.

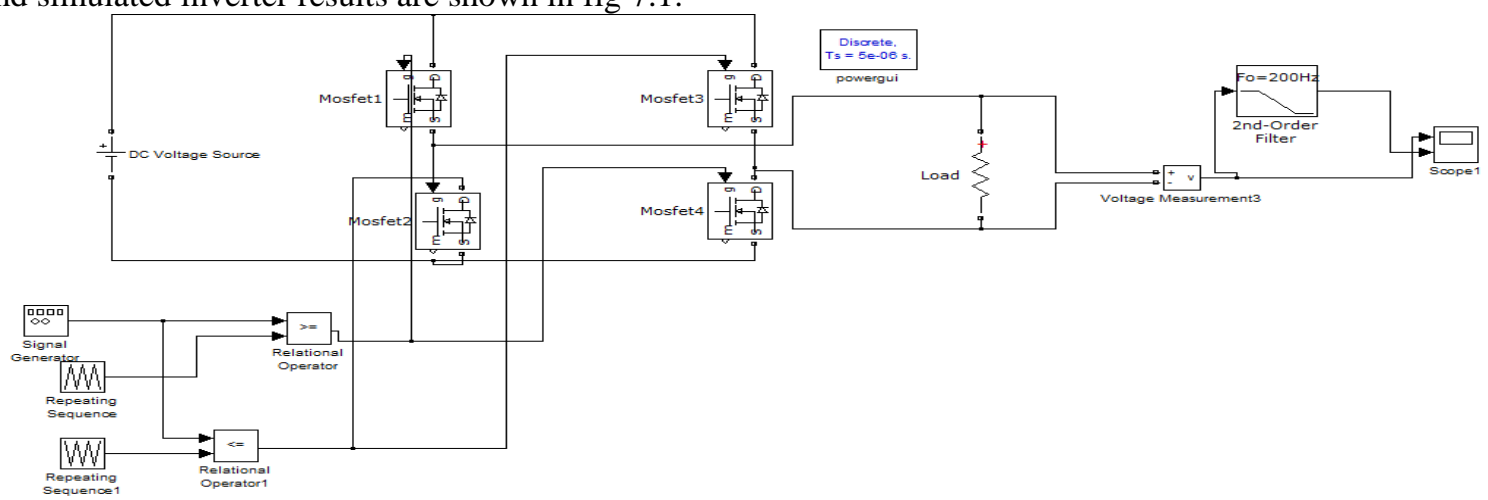

Fig 7 Single phase $\mathrm{H}$ bridge inverter .

V. SIMULINK MODEL OF THE PROPOSED FUEL CELL DISTRIBUTED GENERATION SYSTEM Modeling and Simulation of PEM FC stack is carried out in Matlab /Simulink environment. The output of FC stack model is connected to step-up boost converter, single phase $\mathrm{H}$ bridge inverter using the sim power systems of Matlab to get an AC output. The Complete proposed system is developed in the Matlab/Simulink and is shown in fig(8).

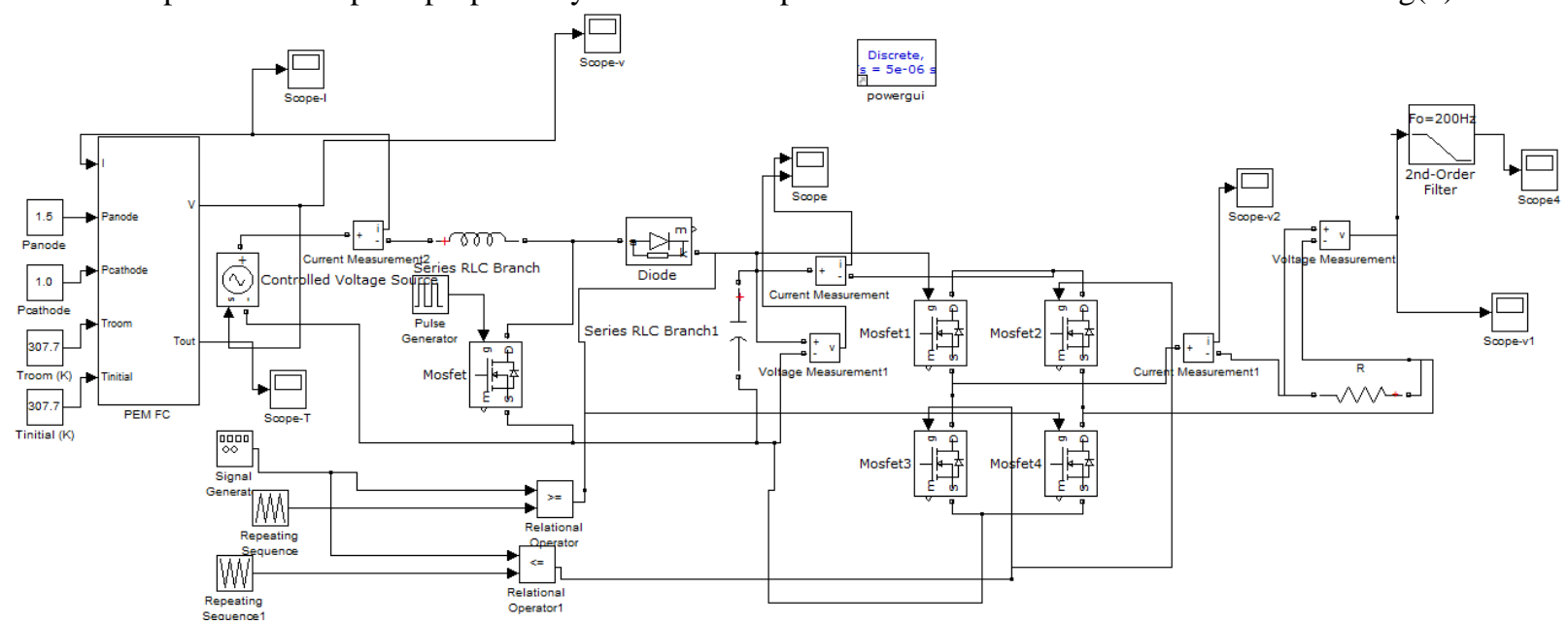

Fig(8) Proposed Simulink model.

VI. SIMULATED RESULTS

1. From the Matlab/Simulink model of PEM fuel cell we got the following characteristics:

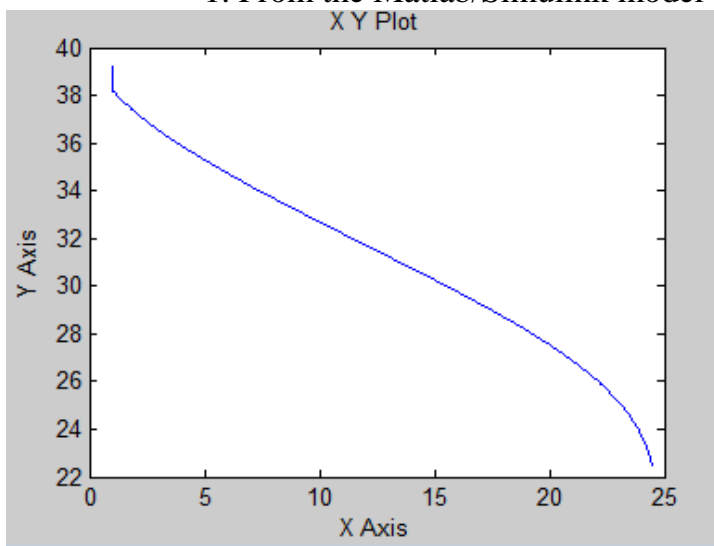

Fig 5.1 Voltage-current Characteristics of Fuel Cell

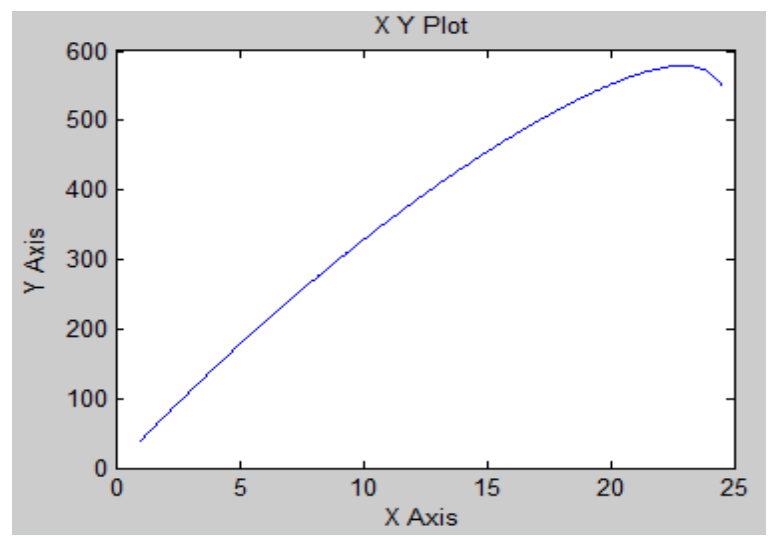

Fig 5.2 Power-current Characteristics of Fuel Cell 
2. Boost output results for voltage and current.

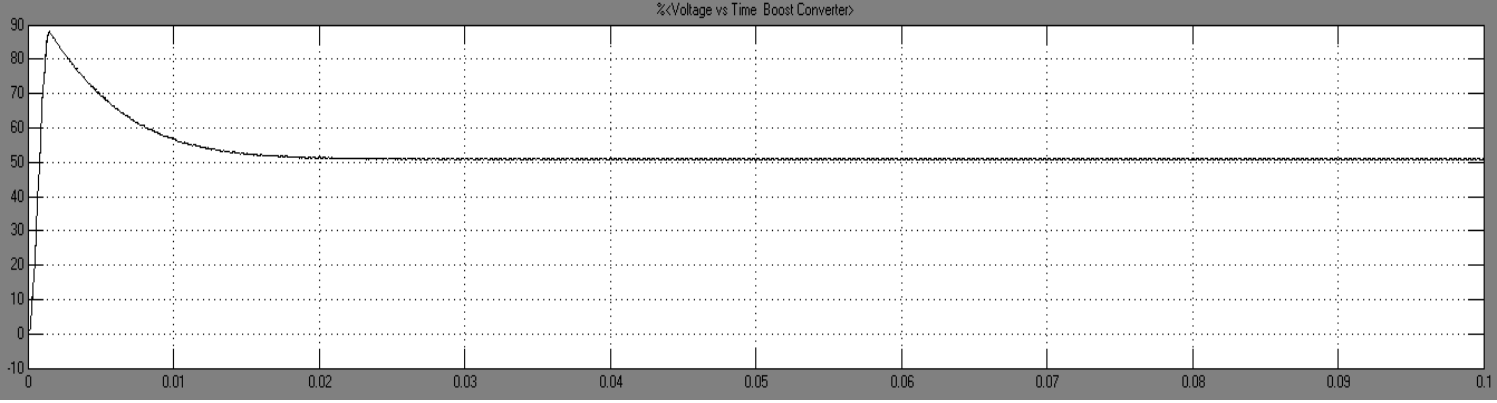

Fig 6.1 Boost output voltage of 50v

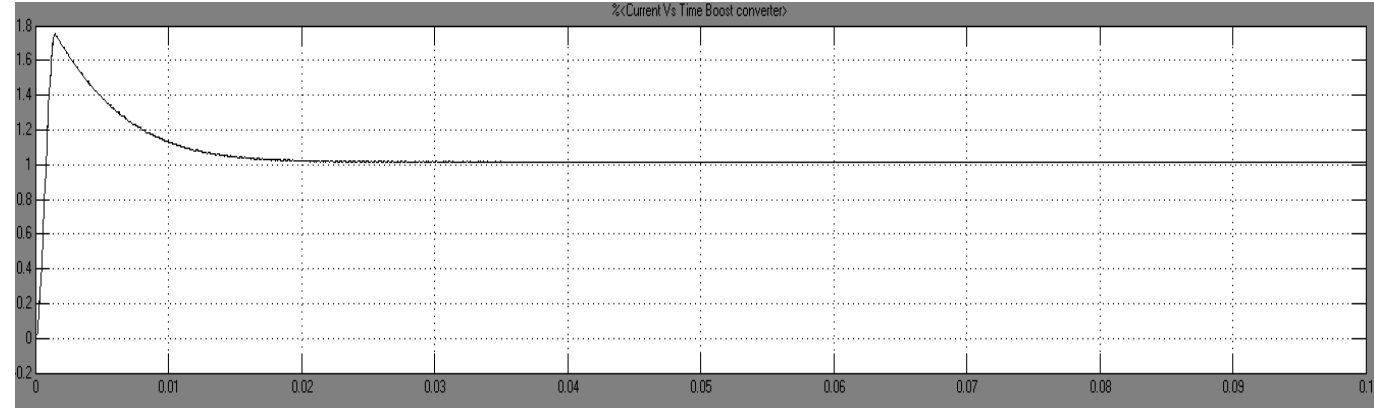

Fig 6.2 Boost output current of 1A

3. Inverter output results

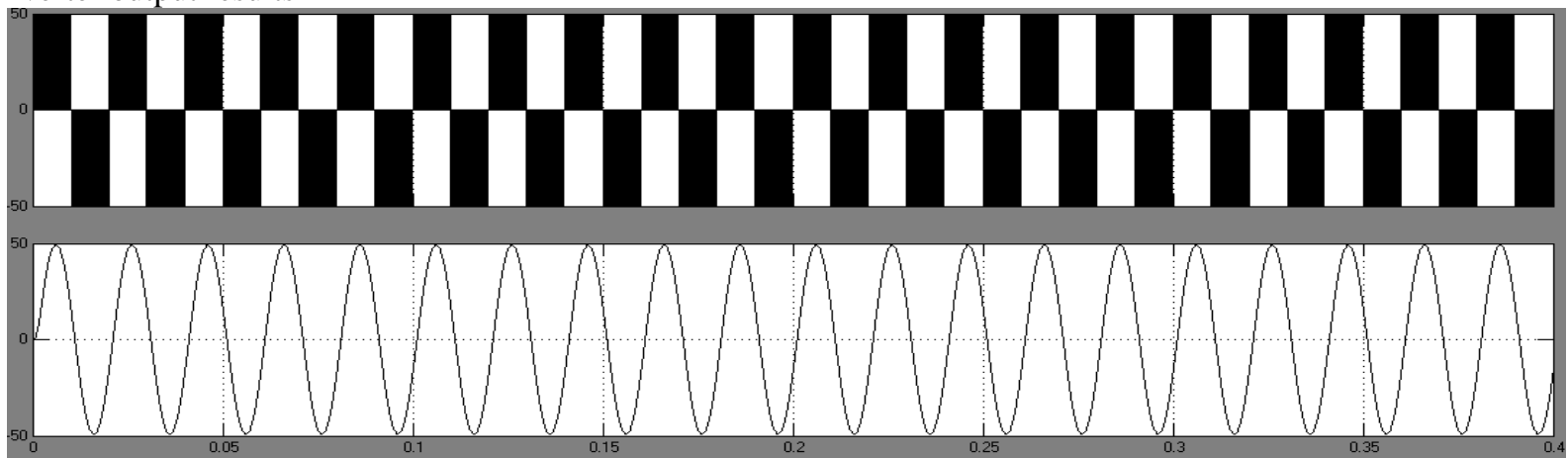

Fig 7.1 Inverter output voltage wave forms without and with filter.

\section{CONCLUSION}

Everywhere in the word renewable energy sources and among them fuel cells are widely used as people are much concerned with the fossil fuel exhaustion and the problems caused by the conventional power generation systems on the environment.PEM fuel cell discussed in this paper have high power density, operate at relatively low temperature and can change output quickly to meet power demand. The simulation of the module layout was successfully carried out using Matlab/Simulink software and the obtained waveforms were observed. The output responses of the step up boost converter are analysed and is then given to inverter for residential applications. All the power electronic circuits are built with Sim Power Systems. The overall system parameters and simulation results are given. Simulation results show an $\mathrm{AC}$ voltage at load side.

\section{REFERENCES}

[1]. Sandeep Gupta,Swati Singh Lini Mathew,"Modeling of the 2.4KW Residential Fuel Cell Based Power Generation System", ,IJART CSSE Volume 3, Issue 9, September 2013.

[2]. M.Vijayalakshmi,A.Alice Hepzibah,”Design and Modeling of PEM Fuel Cell Using PWM based Interleaved Boost Converter “,IJLTET Vol. 2 Issue 1 January 2013.

[3]. Caisheng Wang ,M.Hashem Nehrir and Steven R.Shaw" Dynamic Modeling and Model Validation for PEM fuel cells Using electrical Circuits", IEEE TRANSACTIONS ON ENERGY CONVERSION, VOL. 20, NO. 2, JUNE 2005.

[4]. Muhammad H. Rashid,"power electronics: circuits, devices, and applications".

[5]. A report on DC/AC pure sine wave inverter by Jim Doucet, Dan Eggleston,Jeremy Shaw WPI sponsed by NECAAMSID. 